Reading
Sedgwick 


$$
\underline{1}
$$




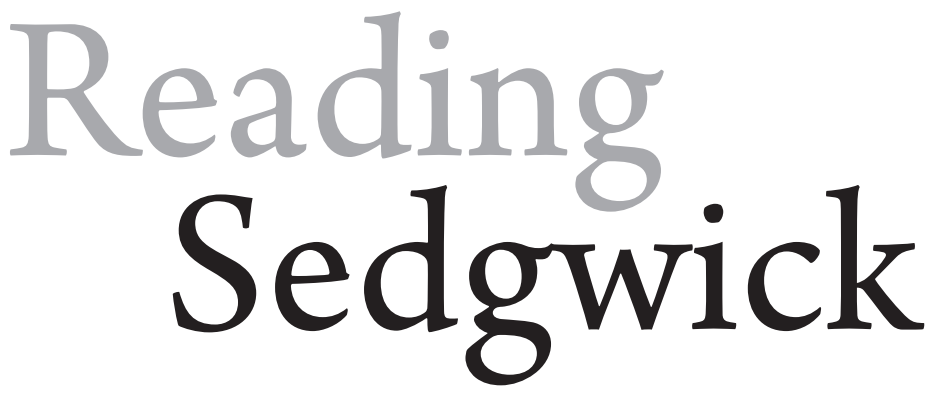

LAUREN BERLANT, EDITOR 
(C) 2019 Duke University Press

All rights reserved

Printed in the United States of America

on acid-free paper $\infty$

Designed by Amy Ruth Buchanan

Typeset in Arno Pro by Westchester

Publishing Services

Library of Congress Cataloging-in-

Publication Data

Names: Berlant, Lauren Gail, [date] editor.

Title: Reading Sedgwick / Lauren Berlant, ed.

Description: Durham : Duke University Press, 2019. | Series: Theory Q |

Includes bibliographical references and index.

Identifiers: LCCN 2019002425 (print) |

LCCN 2019009531 (ebook)

ISBN 9781478005339 (ebook)

ISBN 9781478005001 (hardcover : alk. paper)

ISBN 9781478006312 (pbk. : alk. paper)

Subjects: LCSH: Sedgwick, Eve Kosofsky-

Criticism and interpretation. |

Homosexuality and literature-History-

2oth century. | Gays' writings-History and

criticism-Theory, etc.

Classification: LCC PS3569.E316 (ebook) |

LCC PS3569.E316 Z943 2019 (print) |

DDC 818/.5409-dc23

LC record available at

https://lccn.loc.gov/2019002425
"Eve's Triangles, or Queer Studies beside Itself," was originally published in differences 26, no. 1, pp. 48-73. (C) 2015, Brown University and differences: A Journal of Feminist Cultural Studies, published by Duke University Press.

"Race, Sex, and the Incommensurate," by José Esteban Muñoz, was originally published in Queer Futures: Reconsidering Ethics, Activism, and the Political, edited by Elahe Haschemi Yekani, Eveline Kilian, and Beatrice Michaelis. (C) 2013, Routledge, reproduced by permission of Taylor and Francis Books UK.

\section{WE GRATEFULLY ACKNOWLEDGE}

THE SUPPORT OF THE SEDGWICK FOUNDATION IN MAKING THIS PROJECT POSSIBLE.

Cover art: Eve Kosofsky Sedgwick, Tender winds above the snow melt many kinds of suffering, ca. 2002. Cyanotype, stencil, rubber stamp, and sumanigashi on silk. Photograph by Kevin Ryan. Collection of Eve Kosofsky Sedgwick Foundation. (C) Eve Kosofsky Sedgwick Foundation. 